\title{
Copepods (Crustacea, Maxillopoda) from shallow reservoirs
}

\author{
Copépodes (Crustacea, Maxillopoda) em reservatórios rasos
}

Maria Stela Maioli Castilho-Noll1 ${ }^{1}$, Carolina Figueira Câmara² ${ }^{2}$ Maira Favaron Chicone², Érico Hissashi Shibata ${ }^{2}$ and Ligia Roma Stephan ${ }^{2}$

${ }^{1}$ Departamento de Biologia Aplicada à Agropecuária, Universidade Estadual Paulista - UNESP, Jaboticabal, SP, Brazil

e-mail: mstela@fcav.unesp.br

${ }^{2}$ Departamento de Zoologia e Botânica, Universidade Estadual Paulista - UNESP, São José do Rio Preto, SP, Brazil

e-mail: carolinaf_camara@yahoo.com.br; mairachicone@yahoo.com.br; hishibata@gmail.com; ligia.roma@terra.com.br

\begin{abstract}
Aim: Among the planktonic microcrustaceans, copepods Cyclopoida and Calanoida are the most representative groups, being the largest biomass of the plankton community. The aim of this work is to catalogue and analyze the distribution of copepod species (Crustacea, Maxillopoda) in pelagic and littoral zones from small reservoirs in the northwest of the Sáo Paulo State, in dry and rainy seasons (2007 and 2009). Methods: Zooplankton samplings were carried out in littoral and pelagic zones of 13 small shallow reservoirs (mean depth: $2.6 \mathrm{~m})$ using vertical hauls and plankton net $(45 \mu \mathrm{m})$. Water physical and chemical parameters were also monitored with a multiparameter Horiba U10. Results: Eighteen species of copepods were identified, 13 Cyclopoida and 5 Calanoida. There was no statistical difference between the distributions of species from the littoral and pelagic zones and neither between dry and rainy seasons. Three species occurred exclusively in the littoral zone - Eucyclops elegans, Paracyclops chiltoni and Mesocyclops ogunnus. Tropocyclops prasinus and Thermocyclops decipiens were the most frequent species in the studied environments. Conclusion: Our data suggest that in shallow reservoirs copepods present a homogeneous distribution between the littoral and pelagic zones and Cyclopoida are more diverse than Calanoida. Shallow depths and eutrophic state may be regarded as limiting conditions for the development of Calanoida in these reservoirs.
\end{abstract}

Keywords: copepods, cyclopoida, calanoida, littoral zone, shallow lakes.

Resumo: Objetivo: Dentre os microcrustáceos planctônicos, os copépodes Cyclopoida e Calanoida são um dos grupos mais representativos, contribuindo com a maior biomassa para a comunidade planctônica. O presente trabalho tem o objetivo de caracterizar as comunidades de copépodes (Crustacea, Maxillopoda) pelágicos e litorâneos presentes em pequenos reservatórios na região noroeste do Estado de São Paulo, nas estações seca e chuvosa de 2007 a 2009. Material e métodos: As amostragens foram realizadas tanto na zona litorânea quanto pelágica de 13 pequenos reservatórios rasos (média de 2,6 m), através de arrastos verticais com rede de plâncton $(45 \mu \mathrm{m})$. Parâmetros físicos e químicos da água também foram avaliados utilizando-se o aparelho Horiba U10. Resultados: Foram identificadas 18 espécies de copépodes, sendo 13 Cyclopoida e 5 Calanoida. Não houve diferença estatística entre as distribuições das espécies nas zonas litorâneas e pelágicas bem como entre as estaçôes. Três espécies ocorreram exclusivamente na zona litorânea - Eucyclops elegans, Paracyclops chiltoni e Mesocyclops ogunnus. As espécies Tropocyclops prasinus e Thermocyclops decipiens foram as mais frequentes nos ambientes estudados. Conclusáo: Nossos dados sugerem que, em reservatórios rasos, Copepoda não apresenta diferenças significativas na ocupação das regiôes litorânea e pelágica e que a diversidade de Cyclopoida é maior do que Calanoida. Características tais como baixa profundidade e estado eutrófico podem ser consideradas como condiçóes limitantes para o desenvolvimento de espécies de Calanoida nesses reservatórios estudados.

Palavras-chave: copépodes, cyclopoida, calanoida, zona litorânea, lagos rasos. 


\section{Introduction}

Among microcrustacean planktonic, the copepods Cyclopoida and Calanoida are one of the most representatives, being the largest biomass of the plankton community (Rocha and MatsumuraTundisi, 1984; González et al., 2008). These microcrustaceans can be found in a wide variety of lentic environments, in littoral and pelagic zones (Williamson and Reid, 2001). In the zooplankton community, copepods are commonly dominated by one or both species of the Calanoida and Cyclopoida.

Calanoida and Cyclopoida species have been recorded in São Paulo State since the late nineteenth and early twentieth century. However, it was from the 1970's that the knowledge about these microcrustaceans increased, when limnology studies from several reservoirs in the state were intensified (Matsumura-Tundisi and Silva, 1999).

Shallow reservoirs are found in almost all farms in country areas of Brazil. These lentic environments provide the establishment of zooplankton communities, which are important links in the trophic webs. The shallow characteristics of these aquatic ecosystems present, especially in its littoral areas, a high species richness of macrophytes which, while fostering diversity of habitats and micro-habitats, also increase the number of aquatic species. High zooplankton diversity has been linked with high macrophytes diversity in other studies (Matsumura-Tundisi et al., 1990; Nunes et al.,
1996; Nogueira et al., 2003; Maia-Barbosa et al., 2008). Besides the diversity, high abundance of zooplankton has also been found in littoral areas (Walseng et al., 2006). These studies show the importance of zooplankton sampling in the littoral zones.

Few studies report the distribution of copepods species in littoral and pelagic zones in lentic aquatic environments. In shallow lakes, almost all species can be found in both zones, but specific information about the habitats preferences of adults and larval stages are scarce. As part of a wider project on the list of species of several groups of animals and plants (Program BIOTA/FAPESP-Virtual Institute of Biodiversity, www.biotasp.org.br), this project aims to survey Calanoida and Cyclopoida copepods species in small and shallow reservoirs in the northwestern region of São Paulo, characterizing its distribution in littoral and pelagic zones.

\section{Material and Methods}

\subsection{Study Area}

Samples were obtained from 13 small and shallow reservoirs located in rural areas in the northwest of the São Paulo State (Figure 1). The climate of the region is considered tropical, hot and rainy (Aw Köppen classification) with a dry season from April to September and a rainy season from October to March. The vegetation consists of semideciduous forest and savanna, which currently consists of only $9 \%$ of the original vegetation, as the

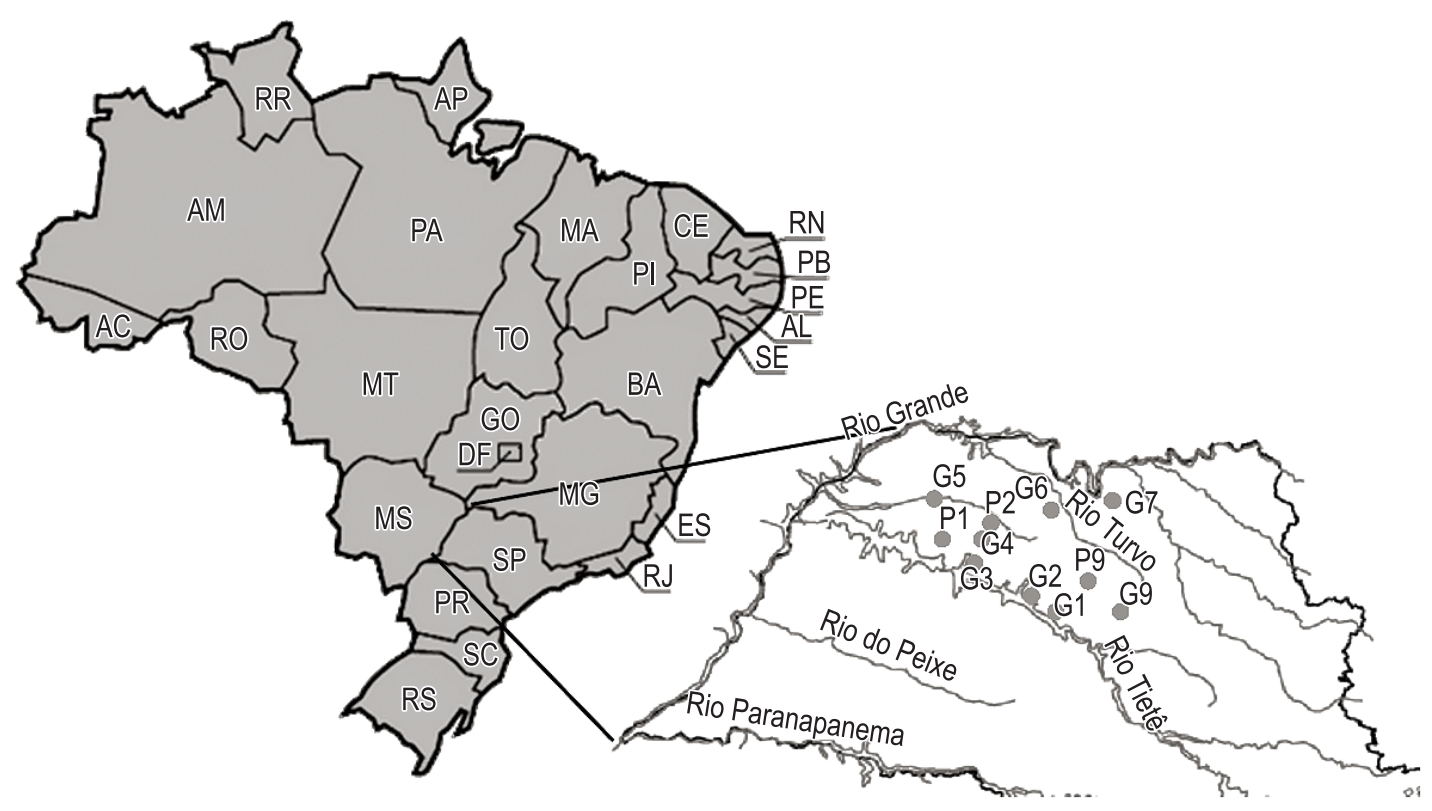

Figure 1. Map of the reservoirs in the northwestern State of São Paulo. 
rest has been transformed into pastures, plantations and urban areas. Table 1 shows the sampling points and some characteristics of the reservoirs.

\subsection{Sampling, qualitative and quantitative assessments of copepods}

Samples were taken by vertical hauls with a $45 \mu \mathrm{m}$ plankton mesh net in the littoral and pelagic zones of all reservoirs. In the littoral zone, sampling always took place in a macrophyte bed when it was available. Samples were taken in the dry season of 2007, wet and dry 2008 and wet 2009. Species identification was carried out under optical microscope, using specific identification keys (Sendacz and Kubo, 1982; Reid, 1985; MatsumuraTundisi, 1986; Silva et al., 1989; Silva and Matsumura-Tundisi, 2005). Nauplii, copepodites and adults of Cyclopoida and Calanoida were counted in $1 \mathrm{~mL}$-subsamples taken with the Stempel pipette, placed in the counting chamber and counted using a stereoscopic microscope. At least sixty individuals were numbered in each subsample; the coefficient of variation did not exceed 0.20 , as recommended (McCauley, 1984). Low-density samples were fully counted.

The constancy of occurrence index of each species was calculated based on Dajoz (1972):
$\mathrm{C}=\mathrm{P} / \mathrm{Q} \times 100$, where: $\mathrm{C}=$ constancy of occurrence of the species (\%), $\mathrm{P}=$ number of samples where the species occurred and $\mathrm{Q}=$ total number of samples. According to the result, the species can be classified as: Constant ( $\mathrm{C}>50 \%)$; Acessorie $(25 \% \leq \mathrm{C} \leq 50 \%)$ or Accidental $(\mathrm{C}<25 \%)$. Richness, diversity of Shannon-Wiener, evenness and Simpson's dominance indices were calculated following the recommendations of Magurran (2011). T-test was used to compare data of diversity and abundance of Cyclopoida and Calanoida between the littoral and pelagic zones.

In the pelagic zone, some environmental variables such as depth $(\mathrm{m})$ and water transparency (m) were measured with a Secchi disk, while other physical and chemical variables such as temperature $\left({ }^{\circ} \mathrm{C}\right)$, dissolved oxygen $\left(\mathrm{mg} . \mathrm{L}^{-1}\right), \mathrm{pH}$ and conductivity $\left(\mu \mathrm{S} . \mathrm{cm}^{-1}\right)$ were obtained with a multiparameter Horiba U-10.

To verify the correlation between copepods' abundances and environmental variables, we performed a canonical correspondence analysis (CCA) with the CANOCO 4.5 (Ter Braak and Smilauer, 2002). Stability and significance of the CCA were evaluated by means of the Monte Carlo. Figure 2 lists the names of copepods with their respective codes used in the analysis.

Table 1. Location, depth, and characteristics of the reservoirs and land use in the northwest of São Paulo State.

\begin{tabular}{|c|c|c|c|c|}
\hline Reservoirs & City & Coordinates & Depth & Land use \\
\hline $\mathrm{P} 1$ & Vicentinópolis & 50 W 2051" and 20 S 560" & $\begin{array}{l}\text { Littoral } 0.5 \mathrm{~m} \\
\text { Pelagic } 1.8 \mathrm{~m}\end{array}$ & Forest and culture \\
\hline $\mathrm{P} 2$ & Macaubal & 49 W 5613" and 20 S 4440" & $\begin{array}{l}\text { Littoral } 0.3 \mathrm{~m} \\
\text { Pelagic } 2.4 \mathrm{~m}\end{array}$ & Culture \\
\hline P9 & Pindorama & 48 W 5541" and 21 S 1331" & $\begin{array}{l}\text { Littoral } 0.5 \mathrm{~m} \\
\text { Pelagic } 3.6 \mathrm{~m}\end{array}$ & Forest \\
\hline G1 & Novo Horizonte & 49 W 1829" and 21 S 3010" & $\begin{array}{l}\text { Littoral } 0.8 \mathrm{~m} \\
\text { Pelagic } 2.1 \mathrm{~m}\end{array}$ & Culture \\
\hline G2 & Sales & 49 W 2959" and 21 S 2533" & $\begin{array}{l}\text { Littoral } 0.3 \mathrm{~m} \\
\text { Pelagic } 2.4 \mathrm{~m}\end{array}$ & Forest \\
\hline G3 & Planalto & 49 W 5841" and 21 S 0054" & $\begin{array}{l}\text { Littoral } 0.7 \mathrm{~m} \\
\text { Pelagic } 3.8 \mathrm{~m}\end{array}$ & Forest and culture \\
\hline G4 & União Paulista & 49 W 5517" and 20 S 5428" & $\begin{array}{l}\text { Littoral } 2.1 \mathrm{~m} \\
\text { Pelagic } 4.9 \mathrm{~m}\end{array}$ & Culture \\
\hline G5 & Magda & 50 W 1143" and 20 S 320" & $\begin{array}{l}\text { Littoral } 0.2 \mathrm{~m} \\
\text { Pelagic } 1.3 \mathrm{~m}\end{array}$ & Forest and culture \\
\hline G6 & Onda Verde & 49 W 1615" and 20 S 3352" & $\begin{array}{l}\text { Littoral } 0.9 \mathrm{~m} \\
\text { Pelagic } 3.7 \mathrm{~m}\end{array}$ & Forest \\
\hline G7 & Barretos & 48 W 5031" and 20 S 293,9" & $\begin{array}{l}\text { Littoral } 0.8 \mathrm{~m} \\
\text { Pelagic } 1.8 \mathrm{~m}\end{array}$ & Forest \\
\hline G91 & Matão & 48 W 3312" and 21 S 3618" & $\begin{array}{l}\text { Littoral } 1.3 \mathrm{~m} \\
\text { Pelagic } 2.4 \mathrm{~m}\end{array}$ & Forest \\
\hline G92 & Matão & 48 W 3247" and 21 S 3100" & $\begin{array}{l}\text { Littoral } 0.6 \mathrm{~m} \\
\text { Pelagic } 1.9 \mathrm{~m}\end{array}$ & Forest \\
\hline G93 & Matão & 48 W $3033 "$ and 21 S 3625" & $\begin{array}{l}\text { Littoral } 0.2 \mathrm{~m} \\
\text { Pelagic } 2.5 \mathrm{~m}\end{array}$ & Culture \\
\hline
\end{tabular}




\section{Results}

\subsection{Limnological variables}

Reservoirs showed a low average depth (2.6 m), and, as expected, a slight increase occurred during the rainy season, when the average was $3.0 \mathrm{~m}$ (Table 2). Transparency was low in some reservoirs, P2 in the dry season, but high in others, G3 and G4. The water temperature ranged from 18.1 to $24.9^{\circ} \mathrm{C}$ in the dry season and increased to 24.5 to $28.4^{\circ} \mathrm{C}$ in the rainy season. During both seasons, $\mathrm{pH}$ ranged from 5 to 8.4, with the highest values in P9, G2, G6, G7 and G93. Almost all reservoirs showed low conductivity values - ca. $20 \mu \mathrm{S} . \mathrm{cm}^{-1}$ - but in the rainy season, G5 and G93 showed conductivity above 100 and $140 \mu \mathrm{S} . \mathrm{cm}^{-1}$, respectively. Dissolved oxygen concentrations were lower in the rainy season than in the dry season in all reservoirs, ranging from 2.6 to $8.0 \mathrm{mg} . \mathrm{L}^{-1}$ in the dry season and 1.2 to $5.7 \mathrm{mg} . \mathrm{L}^{-1}$ in the rainy season.

\subsection{Copepoda}

Eighteen species of Copepoda were identified in the studied reservoirs, 13 Cyclopoida and 5 Calanoida (Table 3). Most species occurred both in the littoral and pelagic zone, except Eucyclops elegans (Herrick, 1884), Paracyclops chiltoni (Thomson, 1882) and Mesocyclops ogunnus Onabamiro, 1957, that occurred exclusively in the littoral zone. Some species were found in only one of the seasons, as Euclyclops elegans, Macrocyclops albidus (Jurine, 1820), Mesocyclops ogunnus and Microcyclops anceps anceps (Richard, 1897) in rainy season and Argyrodiaptomus azevedoi (Wright, 1935) in the dry season.

The average species richness per reservoirs showed no differences between points located in the littoral and pelagic zone (Table 4) but was statistically higher in the rainy than in dry season $(\mathrm{t}=-2.5, \mathrm{p}=0.01, \mathrm{n}=15)$. The Shannon-Wiener diversity index average ranged from 0.3 to 0.6 and no statistical difference between points or season was found. The Simpson dominance index and evenness were around 0.5 and also showed no statistical difference between points or season.

Thermocyclops decipiens (Kiefer, 1920) and Tropocyclops prasinus (Kiefer, 1931) showed the highest occurrence frequencies in the reservoirs (Figure 2), and were classified as constant species for both the dry and rainy seasons. All other species were classified as accidental species because they presented low frequency of occurrence in the collected samples.
T. decipiens was also the most abundant species of Cyclopoida, followed by $T$. prasinus, especially in the dry season (Figure 3). Calanoida were more abundant in the dry season, especially of Notodiaptomus conifer Sars, 1901 (Figure 4).

Nauplius was the most abundant copepod stage in the pelagic and littoral zones (Figure 5). In the dry season, they reached the highest density values, above $50,000 \mathrm{ind} / \mathrm{m}^{3}$, especially in the pelagic zone, and in the rainy season the highest abundance of nauplii was observed in the littoral zone. In the dry season, copepodites were more abundant in the pelagic zone (Figure 5) and in the rainy season, high densities of this stage were observed in littoral. Adult Cyclopoida were more abundant than calanoids, occurring in higher density in the pelagic than in the littoral zone (Figure 5). Calanoida were more abundant in the littoral than in the pelagic zone, with a significant decrease in the rainy season.

The principal environmental variables, according to the CCA analysis, were depth $(\mathrm{p}=0.020)$, conductivity $(\mathrm{p}=0.060)$ and transparency $(\mathrm{p}=0.048)$ (Figure 6). Depth correlated positively with the species Notodiaptomus iheringi Wright, 1935, and Paracyclops chiltoni at G4 and G3 points. Dissolved oxygen explained the occurrence of Microcyclops alius Kiefer, 1935 in P2. Higher temperature explained the distribution of Mesocyclops meridianus (Kiefer,1926) and Argyrodiaptomus azevedoi in G2, G5 and G9. Transparency was positively related to Mesocyclops cf. brasilianus. A group of species, among them Dipatomidae sp., Macrocyclops albidus, Argyrodiaptomus furcatus Sars, 1901, Thermocyclops minutus (Lowndes, 1934) and Notodiaptomus conifer, showed no correlation with the variables measured in this study. These species were found in P1 and G1.

\section{Discussion}

The reservoirs were shallow and small, and the physical and chemical variables varied between the dry and rainy seasons. The lowest depths observed during the rainy season in three reservoirs could be related to the management activity of the reservoir to prevent flooding and emptying. The transparency and oxygen concentrations appeared to influence the species occurrence. The low oxygen concentration, even with the increase of temperature in summer, can be explained by the increase in decomposition rates, typical of shallow waters, whose lower $\mathrm{pH}$ values also indicate high decomposition rates in these environments (Wetzel, 
Table 2. Physical and chemical variables analyzed in the reservoirs during the dry and rainy seasons.

\begin{tabular}{|c|c|c|c|c|c|c|c|c|c|c|c|c|c|c|}
\hline & & P1 & P2 & P9 & G1 & G2 & G3 & G4 & G5 & G6 & G7 & G91 & G92 & G93 \\
\hline \multirow[t]{2}{*}{ Depth (m) } & Dry & 1.8 & 2.4 & 3.4 & 2.1 & 2.4 & 3.8 & 4.9 & 1.3 & 3.7 & 1.6 & 2.4 & 1.9 & 2.5 \\
\hline & Rainy & 2.2 & 2.3 & 2.2 & 1.8 & - & 4.5 & 4.9 & 1.9 & 2.5 & 3.9 & - & 3.2 & 3.5 \\
\hline \multirow[t]{2}{*}{ Transparency (m) } & Dry & 1.8 & 0.2 & 1.3 & 2.0 & 1.0 & 1.9 & 2.6 & 0.9 & 2.2 & 1.4 & 1.2 & 0.8 & 1.1 \\
\hline & Rainy & 2.2 & 0.6 & 0.7 & 0.8 & - & 3.0 & 2.6 & 1.4 & 0.8 & 1.1 & - & 0.8 & 1.2 \\
\hline \multirow[t]{2}{*}{ Temperature $\left({ }^{\circ} \mathrm{C}\right)$} & Dry & 23.5 & 18.8 & 22.9 & 22.4 & 23.0 & 18.1 & 19.0 & 25.1 & 22.3 & 24.9 & 22.9 & 23.2 & 23.3 \\
\hline & Rainy & 24.8 & 24.5 & 25.9 & 25.1 & - & 25.7 & 26.1 & 25.6 & 25.5 & 28.4 & - & 25.2 & 24.5 \\
\hline \multirow[t]{2}{*}{$\mathrm{pH}$} & Dry & 6.3 & 6.4 & 7.6 & 5.8 & 7.8 & 5.9 & 6.2 & 6.8 & 6.7 & 6.5 & 5.7 & 6.3 & 7.9 \\
\hline & Rainy & 5.0 & 5.6 & 7.3 & 5.5 & - & 5.7 & 6.2 & 6.3 & 8.4 & 7.8 & - & 5.4 & 6.6 \\
\hline \multirow{2}{*}{$\begin{array}{l}\text { Conductivity } \\
(\mu \mathrm{S} / \mathrm{cm})\end{array}$} & Dry & 12.0 & 10.0 & 80.3 & 2.0 & 54.0 & 20.0 & 10.0 & 43.0 & 49.1 & 14.3 & 16.0 & 42.0 & 55.0 \\
\hline & Rainy & 17.3 & 27.0 & 52.7 & 4.0 & - & 13.3 & 25.5 & 100.7 & 12.8 & 3.6 & - & 48.0 & 141.7 \\
\hline \multirow[t]{2}{*}{ DO (mg/L) } & Dry & 5.8 & 5.8 & 7.8 & 6.1 & 6.6 & 5.6 & 6.8 & 3.8 & 6.3 & 6.7 & 2.6 & 3.7 & 8.0 \\
\hline & Rainy & 4.8 & 5.5 & 4.0 & 5.7 & - & 3.0 & 3.6 & 1.6 & 3.4 & 3.3 & - & 1.2 & 3.8 \\
\hline
\end{tabular}

Table 3. Cyclopoida and Calanoida species with respective densities in littoral and pelagic zones of reservoirs in the northwestern region of São Paulo, in the dry and rainy seasons.

\begin{tabular}{|c|c|c|c|c|c|}
\hline & & \multicolumn{2}{|c|}{ Dry } & \multicolumn{2}{|c|}{ Rainy } \\
\hline & & Littoral & Pelagic & Littoral & Pelagic \\
\hline \multicolumn{6}{|l|}{ Cyclopoida } \\
\hline \multirow[t]{6}{*}{ Eucyclopinae } & Eucyclops elegans (Herrick, 1884)* & & & & \\
\hline & Macrocyclops albidus (Jurine, 1820) & & & & \\
\hline & Paracyclops chiltoni (Thomson, 1882) & & & & \\
\hline & Tropocyclops prasinus (Kiefer, 1931) & & & & \\
\hline & Tropocyclops prasinus meridionalis (Kiefer, 1931) & & & & \\
\hline & Tropocyclops prasinus prasinus (Fischer, 1860) & & & & \\
\hline \multirow[t]{7}{*}{ Cyclopinae } & Mesocyclops cf. brasilianus & & & & \\
\hline & Mesocyclops meridianus (Kiefer,1926) & & & & \\
\hline & Mesocyclops ogunnus Onabamiro, $1957^{*}$ & & & & \\
\hline & Microcyclops alius Kiefer, 1935 & & & & \\
\hline & Microcyclops anceps anceps (Richard, 1897) & & & & \\
\hline & Thermocyclops decipiens (Kiefer, 1920) & & & & \\
\hline & Thermocyclops minutus (Lowndes, 1934) & & & & \\
\hline \multicolumn{2}{|c|}{ Cyclopoida density (ind/m³) } & 63474.4 & 95348.5 & 83441.2 & 68984.8 \\
\hline \multicolumn{6}{|l|}{ Calanoida } \\
\hline \multirow[t]{5}{*}{ Diaptominae } & Argyrodiaptomus furcatus Sars, 1901 & & & & \\
\hline & Argyrodiaptomus azevedoi (Wright, 1935) & & & & \\
\hline & Notodiaptomus conifer (Sars, 1901) & & & & \\
\hline & Notodiaptomus iheringi (Wright, 1935) & & & & \\
\hline & Diaptominae sp. & & & & \\
\hline \multicolumn{2}{|c|}{ Calanoida density (ind/m³) } & 30325.5 & 14165.5 & 3394.7 & 259.5 \\
\hline
\end{tabular}

$<100$ ind. $/ \mathrm{m}^{3} ; \quad 101-1000$ ind.$/ \mathrm{m}^{3}$; $>1000$ ind. $/ \mathrm{m}^{3}$. ${ }^{*}$ Species that have occurred exclusively in the littoral zone.

Table 4. Species richness (S) variation, mean and standard deviation of Shannon-Wiener diversity (H'), Simpson dominance (D) and evenness (e) indices of Copepoda found in the littoral and pelagic zones of reservoirs during the dry and rainy seasons from 2007 to 2009.

\begin{tabular}{lcccccc}
\hline & \multicolumn{2}{c}{ Dry } & & \multicolumn{2}{c}{ Rainy } \\
\cline { 2 - 3 } \cline { 5 - 6 } & Littoral & Pelagic & & Littoral & Pelagic \\
\hline Richness (S) & $1.0-3.0$ & $1.0-3.0$ & & $1.0-4.0$ & $1.0-3.0$ \\
Shannon-Wiener diversity $\left(\mathrm{H}^{\prime}\right)$ & $0.4 \pm 0.3$ & & $0.5 \pm 0.2$ & & $0.6 \pm 0.3$ & $0.3 \pm 0.4$ \\
Simpson dominance (D) & $0.7 \pm 0.2$ & & $0.6 \pm 0.2$ & & $0.6 \pm 0.2$ & $0.8 \pm 0.3$ \\
Evenness (e) & $0.5 \pm 0.3$ & $0.7 \pm 0.3$ & & $0.6 \pm 0.3$ & $0.4 \pm 0.4$ \\
\hline
\end{tabular}


2001). Although not a factor assessed in this study, data from eutrophication, obtained in other studies in the same locations (M. S. M. Castilho-Noll and C. F. Câmara, unpublished data) showed that 11 of the 13 reservoirs were eutrophic or hypereutrophic. This classification suggests that these reservoirs are subject to nutrient input from adjacent crops, since they are located in agricultural environments.

Greater diversity of zooplankton species can be found in the littoral of reservoirs, especially those colonized by macrophytes. In these zones, the environmental heterogeneity, with great diversity of niches, allows the colonization of a large number of species, resulting in a high diversity. According to Rocha et al. (1995), comparisons between the littoral and pelagic zones of reservoirs are important aspects to be considered in studies of zooplankton for a better understanding of the diversity of this community. For the Cladocera community, Castilho-Noll et al. (2010) found a significant increase of species richness (approximately 40\%) in samples collected in the littoral zone in the small reservoirs studied here.

Studying both zones, it was not found significant differences between the copepods distribution, as was reported to Cladocera in the same reservoirs (Castilho-Noll et al., 2010). This reflects the habits of most copepods species, mainly Cyclopoida, which are usually associated to a substrate in the littoral zone of aquatic environments (Williamson and Reid, 2001). Thus, although some species have been observed only in littoral areas, it is possible that, unlike what is suggested for Cladocera (Castilho-Noll et al., 2010), especially in shallow lentic ecosystems, most copepods species are not segregated in one of the zones and can occupy most of the microhabitats. Even to the larval stages - nauplii and copepodites - no significant differences were found between the densities in zones in both seasons. This can reinforces the hypothesis that a greater percentage of the copepods species may occupy and develop in two zones, being less demanding with respect to habitat.

The canonical correspondence analysis results suggest that some reservoirs, as P1 and G1, showed specific features that are not explained by the evaluated variables. These features possibly favoured the development of some species that occurred exclusively in those reservoirs. In this way, three of the five calanoids species were found only in these reservoirs.

The composition and abundance of zooplankton species are influenced by changes in the trophic status of aquatic ecosystems (Pinto-Coelho, 1998). Changes in community structure of calanoids, including the disappearance of several species of the lentic ecosystems in São Paulo, are indicated as the result of rapid and intense processes of eutrophication (Arcifa, 1984; Pinto-Coelho, 1998; Tundisi and Matsumura-Tundisi, 2003).

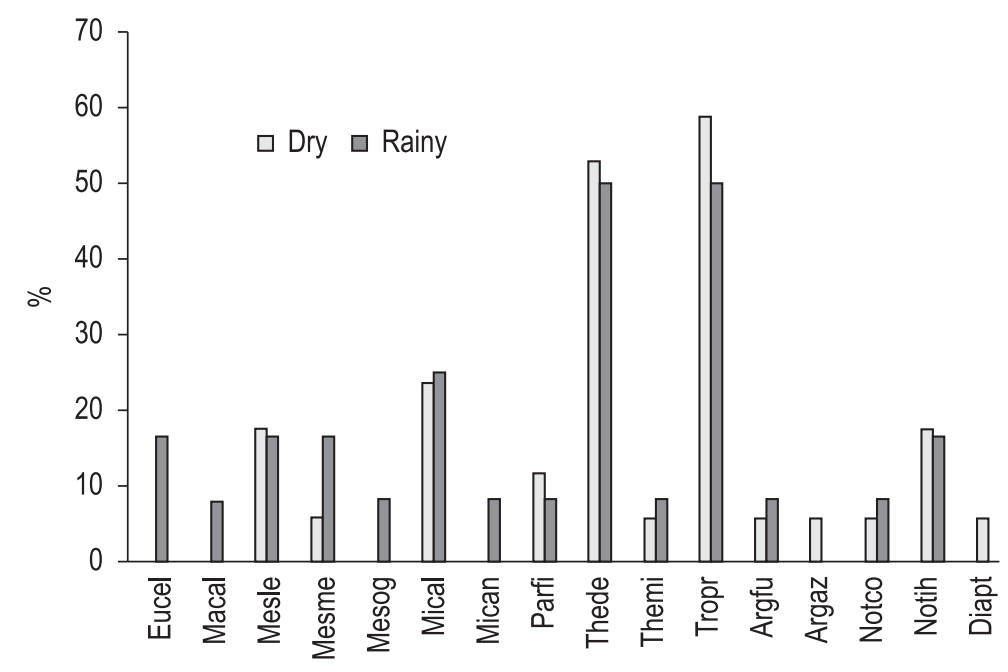

Figure 2. Frequency of occurrence (\%) of copepods species recorded in the reservoirs in the northwest of São Paulo State. $($ Eucel $=$ Eucyclops elegans, Macal = Macrocyclops albidus, Mesle = Mesocyclops cf. brasilianus, Mesme = Mesocyclops meridianus, Mesog = Mesocyclops ogunnus, Mical = Microcyclops alius, Mican = Microcyclops anceps, Parfi = Paracyclops chiltoni, Thede = Thermocyclops decipiens, Themi $=$ Thermocyclops minutus, Tropr $=$ Tropocyclops prasinus, Argfu = Argyrodiaptomus furcatus, Argaz = Argyrodiaptomus azevedoi, Notco = Notodiaptomus conifer, Notih $=$ Notodiaptomus iheringi, Diapt $=$ Diaptomidae sp. . 
The high endemism of Calanoida is restricted to narrow longitudinal bands, mainly due to its high sensitivity to chemical and physical changes of the water (Matsumura-Tundisi, 1986). Temperature is one of this factor that restricts the distribution of some species to certain regions (Matsumura-Tundisi and Silva, 1999). Other factors such as conductivity, $\mathrm{pH}$ and dissolved oxygen in water can also affect community composition of Calanoida. In all 13 studied reservoirs, the four calanoids species were found in only five, reinforcing the idea that the group has restrictions for their establishment. At the moment it is not possible to suggest what conditions they need to survival, or set of them, but it is evident that Calanoida is more sensitive than Cyclopoida which occurred in greater numbers and distribution in all reservoirs.

Calanoids are primarily planktonic (Williamson and Reid, 2001) and besides the trophic state, the shallowness of the reservoirs can be a limiting factor for Calanoida populations development, since they are more adapted to deeper environments, which favour the planktonic communities establishment and development. Feeding habits of these groups may also explain the low frequency of occurrence of them, whose species feed on suspended particles, creating a flow of water with the second antennae. The high levels of suspended material very common in shallow reservoirs can difficult these animals to feed. Some of the studied reservoirs presented decrease in the transparency in rainy season, indicating increasing in the suspended material
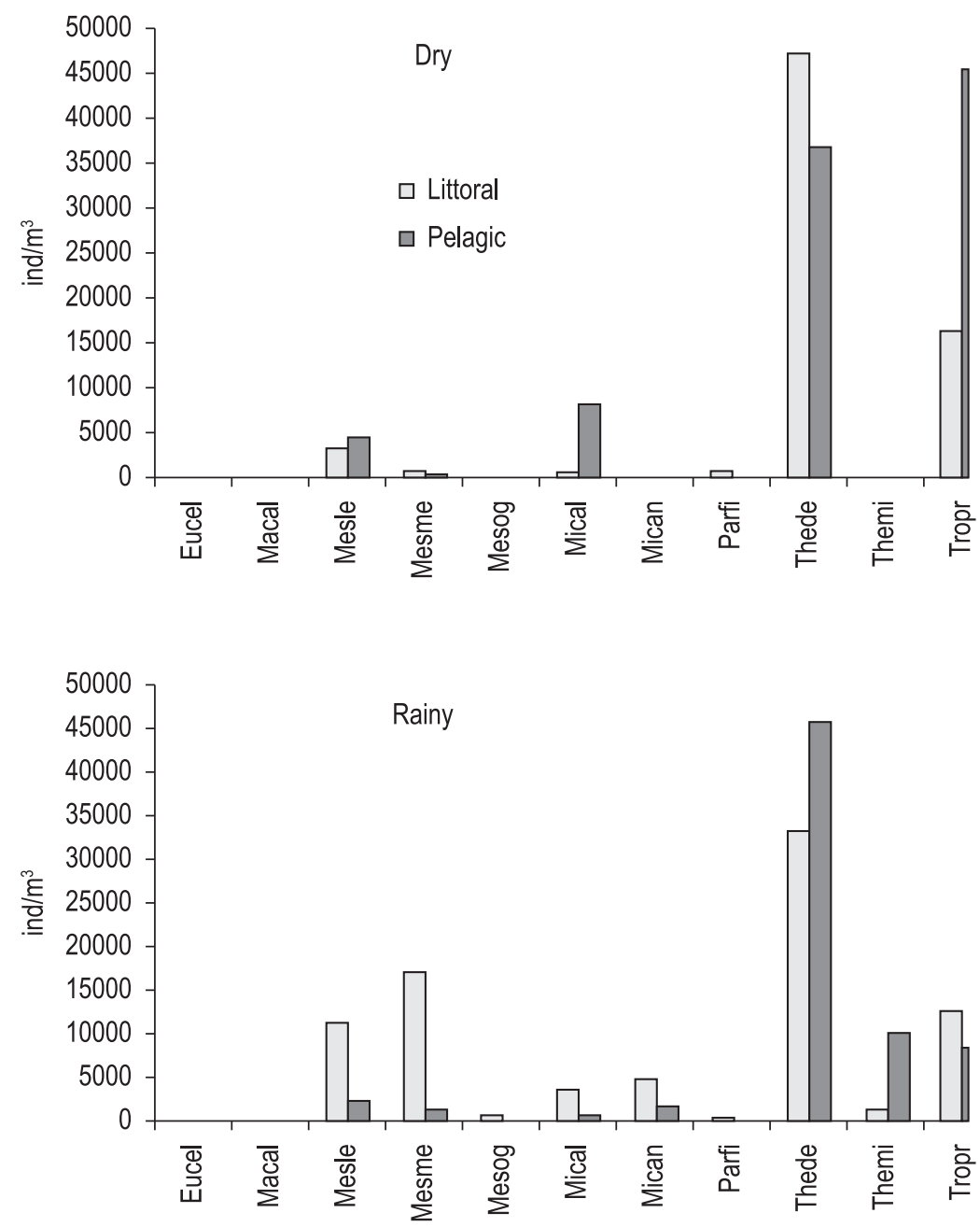

Figure 3. Densities of Cyclopida species registered in the littoral and pelagic zones of the reservoirs during the dry and rainy seasons. (Eucel = Eucyclops elegans, Macal = Macrocyclops albidus, Mesle = Mesocyclops cf. brasilianus, Mesme = Mesocyclops meridianus, Mesog = Mesocyclops ogunnus, Mical = Microcyclops alius, Mican = Microcyclops anceps, Parfi = Paracyclops chiltoni, Thede $=$ Thermocyclops decipiens, Themi $=$ Thermocyclops minutus, Tropr $=$ Tropocyclops prasinus). 
in water, which could be the reason for the lower densities of the Calanoida in the rainy than dry season. On the other hand, Cyclopoida detects the prey by mechanoreceptors and catch them with their first jaw (Williamson and Reid, 2001), the suspended material should not be a problem to it as to Calanoida.

Notodiaptomus iheringi, for example, occurred only in the two reservoirs that had the greatest depths, as shown by canonical correspondence analysis that correlated positively this species and the depth of the reservoirs, mainly the reservoirs G3 and G4, where it occurred which must have been determinant to the occurrence of this species of Calanoida.

According to Tundisi and Matsumura-Tundisi (2003), over the years the anthropogenic impacts in the reservoirs have caused changes in the composition of calanoids in the whole State of São Paulo. In some reservoirs, as in Broa, the replacement of species formerly dominant has been observed, such as Argyrodiaptomus furcatus by $N$. iheringi, which is more tolerant (Rietzler et al. 2002, Tundisi and Matsumura-Tundisi, 2003). The highest frequency and densities of $N$. ihering $i$ in the studied reservoirs can reinforce its higher capacity to tolerate the eutrophic state environments than the other Calanoida species. The association of the occurrence of $N$. iheringi with eutrophic lake have been also sugested by another author (Sendacz, 2001).

Cyclopoida species are more widely distributed than Calanoida, and some species are considered cosmopolitan. Cyclopoida is also considered

Dry

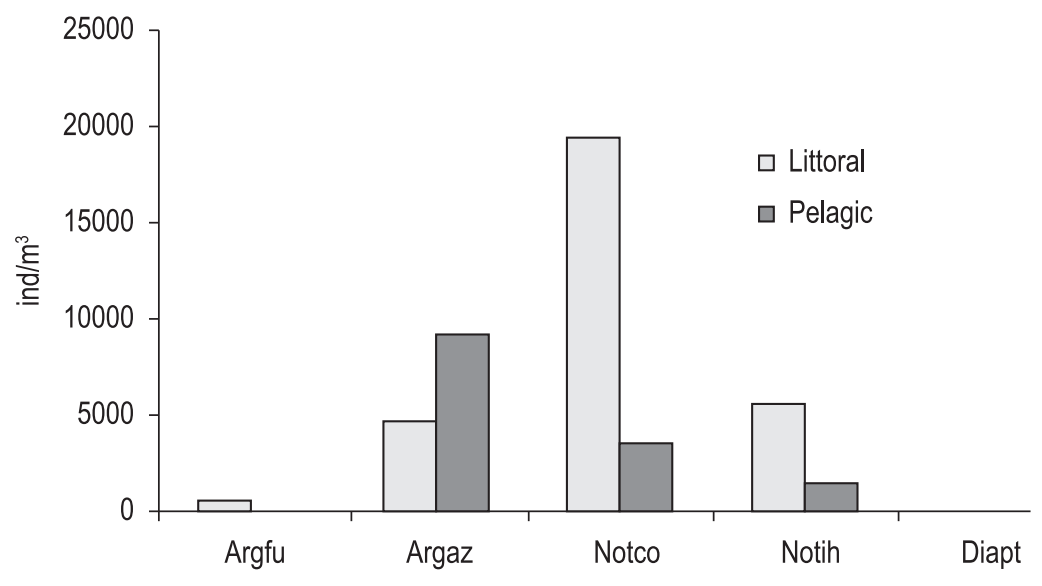

Rainy

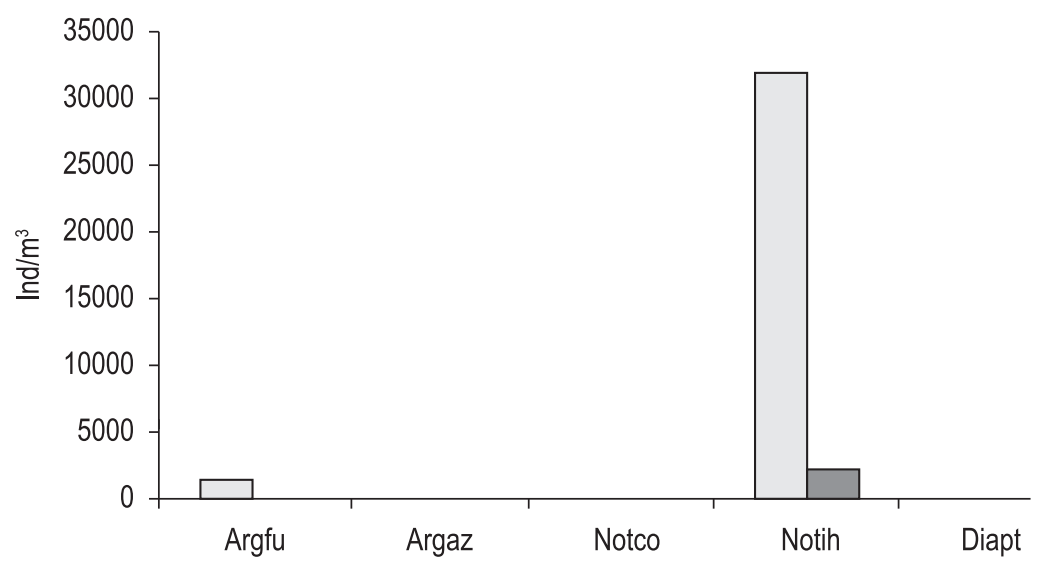

Figure 4. Densities of Calanoida species registered in the littoral and pelagic zones of the reservoirs during the dry and rainy seasons. (Argfu = Argyrodiaptomus furcatus, Argaz = Argyrodiaptomus azevedoi, Notco = Notodiaptomus conifer, Notih $=$ Notodiaptomus iheringi, Diapt $=$ Diaptomidae sp. $)$. 
more tolerant to higher trophic levels than Calanoida (Matsumura-Tundisi and Silva, 1999), which favours its dominance in many eutrophic aquatic environments (Tundisi et al., 1988 apud Matsumura-Tundisi and Silva, 1999).

The Cyclopoida species registered in the reservoirs are part of the fauna of Sáo Paulo State, according to Silva (2008). Silva and Matsumura-Tundisi (2005) also found the species Thermocyclops decipiens as being the most frequent in other reservoirs in São Paulo State. For the authors, this species has a wide distribution, occurring in different environments in all hydrographical basins in the State. It can be considered one of the most abundant species, followed by T. minutus (Singh, 2008). The characteristic of eutrophic reservoirs can also favour $T$. decipiens, since it is dominant in these environments (Silva and Matsumura-Tundisi, 2005). Sendacz (2001) also reported T. decipiens in only one of the lakes in the floodplain of the upper Paraná River (MS), which was considered eutrophic. According to Landa et al. (2007), this species may be used as indicator species of eutrophic environments with low water quality in the state of Minas Gerais.

In conclusion, our data show that communities of copepods, in all stages of development, can occupy and survive as in the pelagic as in the littoral zones of shallow aquatic environments. Cyclopoida has more species than Calanoida, whose frequencies and abundances are also lower. It is possible that the shallow and eutrophic state represent limiting
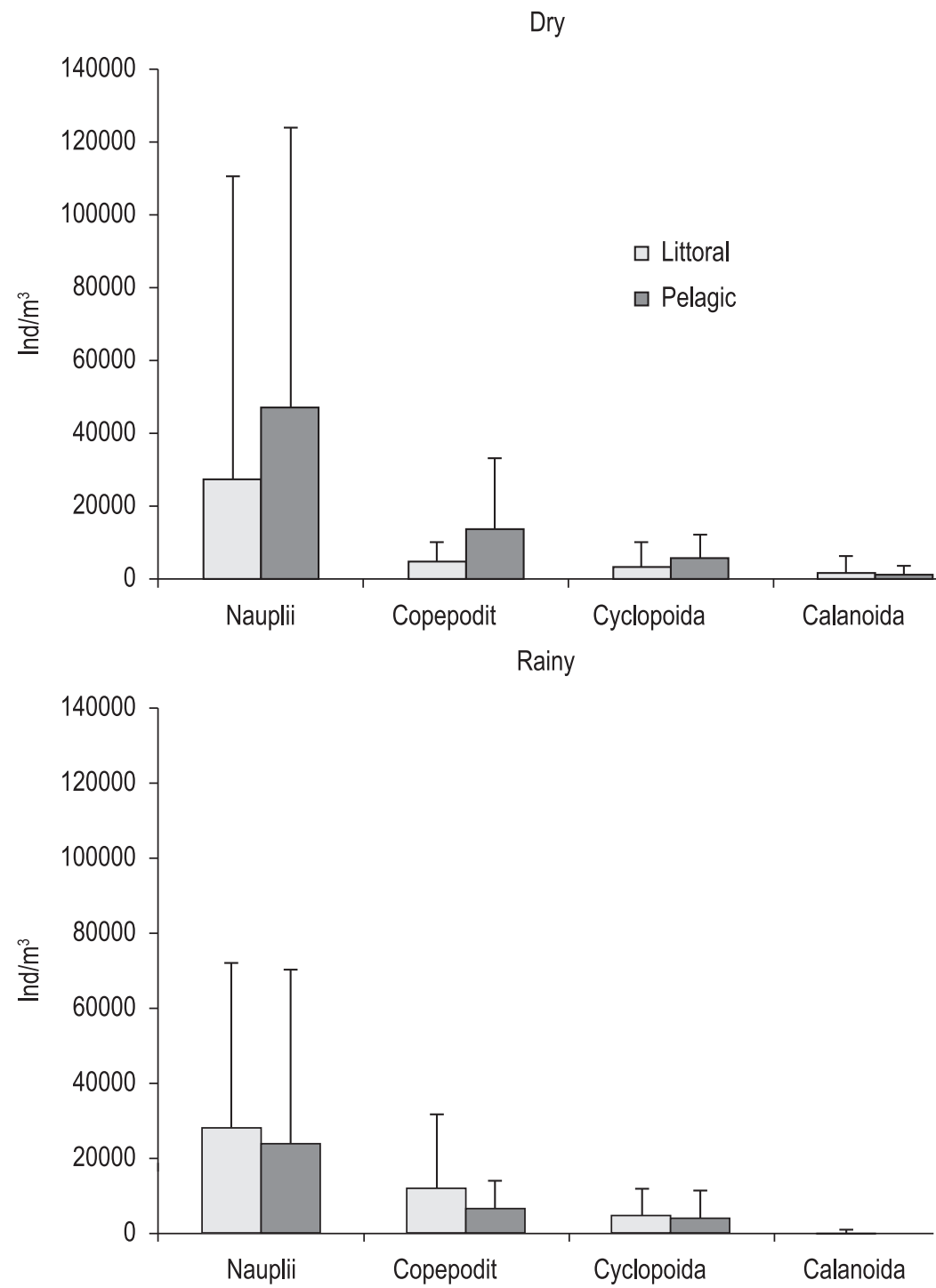

Figure 5. Densities of nauplii, copepodites and adults of Cyclopoida and Calanoida, recorded in the littoral and pelagic zones of the reservoirs during the dry and rainy seasons. 


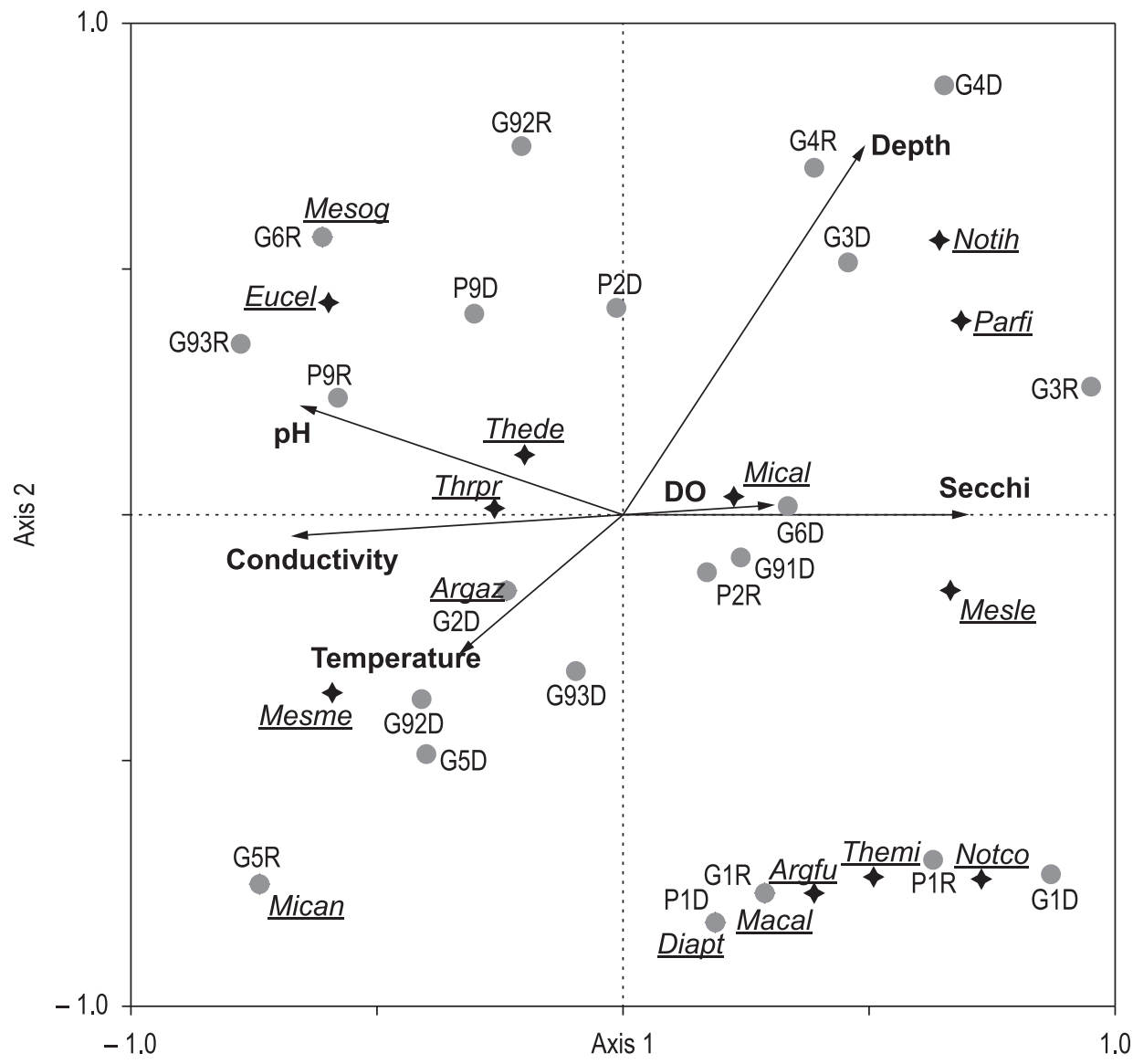

Figure 6. Ordination diagram representing the first two axes of canonical correlation analysis, showing all aquatic environments sampled (circles, with $\mathrm{D}=\mathrm{dry}, \mathrm{R}=$ rainy), species (stars) and environmental descriptors (arrows). The significance test of Monte Carlo (4999 permutations) on the option of full model indicates that the canonical axes are significant $(\mathrm{F}$-ratio $=3.013, \mathrm{P}$-value $=0.03)$. For species codes, see Figure 2.

conditions for the establishment and development of Calanoida in the aquatic environments.

\section{Acknowledgements}

We thank 1 st Company of the $4^{\text {th }}$ Battalion of Environmental Police officer of São José do Rio Preto for helping with part of the fieldwork, M.Sc. G. Perbiche-Neves (UNESP) for the partial identification of copepods and Dr. R. Henry (UNESP) for supporting part of this work. This work was also supported by grants from FAPESP (BIOTA/FAPESP Program, 04/04820-3) and a Post-doctoral fellowship to the senior author (07/05134-4).

\section{References}

ARCIFA, MS. 1984. Zooplankton composition on ten reservoirs in Southern Brazil. Hydrobiologia, vol. 113, no. 1, p. 137-145. http://dx.doi.org/10.1007/ BF00026600

CASTILHO-NOLL, MSM., CÂMARA, CF., CHICONE, MF. and SHIBATA, EH. 2010. Pelagic and littoral cladocerans (Crustacea, Anomopoda and Ctenopoda) from reservoirs of the northwest of São Paulo State, Brazil. Biota neotropica, vol. 10, no. 1, p. 1-10. Available from: <http://www. biotaneotropica.org.br/v10n1/pt/abstract?article+ bn00310012010>.

DAJOZ, R. 1972. Ecologia Geral. São Paulo: Vozes; USP. 474 p.

GONZÁlEZ, EJ., MATSUMURA-TUNDISI, T. and TUNDISI, JG. 2008. Size and dry weight of main zooplankton species in Bariri reservoir (SP, Brazil). Brazilian Journal of Biology, vol. 68, no. 1, p. 69-75. http://dx.doi.org/10.1590/S151969842008000100010

LANDA, GL., BARBOSA, FAR., RIETZLER, AC. and MAIA-BARBOSA, PM. 2007, Thermocyclops decipiens (Kiefer, 1929) (Copepoda, Cyclopoida) as indicator of water quality in the State of Minas Gerais, Brazil. Brazilian Archive of Biology and Technology, vol. 50, no. 4, p. 695-705. http://dx.doi. org/10.1590/S1516-89132007000400015

MAIA-BARBOSA, PM., PEIXOTO, RS. and GUIMARÁES, AS. 2008. Zooplankton in littoral waters of a tropical lake: a revisited biodiversity. 
Brazilian Journal of Biology, vol. 68, no. 4, p. 1069-1078. http://dx.doi.org/10.1590/S151969842008000500014

McCAULEY, E. 1984. The estimation of the abundance and biomass of zooplankton in samples. In DOWNING, JA. and RIGLER, FH., org. A Manual on Methods for the Assessment of Secondary Productivity in Fresh Waters. London: IBP. Blackwell Scientific Publications. 228 p.

MAGURRAN, AE. 2011. Medindo a diversidade biológica. Curitiba: EdUPR. 256 p.

MATSUMURA-TUNDISI, T. 1986. Latitudinal distribution of Calanoida copepods in freshwater aquatic systems of Brazil. Revista Brasileira de Biologia, vol. 46, p. 527-553.

MATSUMURA-TUNDISI, T., LEITÃO, SN., AGHENA, LS. and MIYAHARA, J. 1990. Eutrofização da represa de Barra Bonita: estrutura e organização da comunidade de Rotifera. Revista Brasileira de Biologia, vol. 50, no. 4, p. 923-935.

MATSUMURA-TUNDISI, T. and SILVA, WM. 1999. Crustáceos Copépodos Planctônicos. In ISMAEL, D., VALENTI, WC., MATSUMURA-TUNDISI, T. and ROCHA, O., org. Biodiversidade do Estado de São Paulo, Brasil: síntese do conhecimento ao final do século XX: Invertebrados de Água Doce. São Paulo: Fapesp. 97 p.

NOGUEIRA, MG., GEORGE, DG. and JORCIN, A. 2003. Estudo do zooplâncton em zonas litorâneas lacustres: um enfoque metodológico. In HENRY, R., org. Ecótonos nas Interfaces dos Ecossistemas Aquáticos. São Carlos: Rima, 83 p.

NUNES, MA., LANSAC-TÔHA, FA., BONECKER, CC., ROBERTO, MC. and RODRIGUES, L. 1996. Composiçáo e abundância do zooplâncton de duas lagoas do Horto Florestal Dr. Luiz Teixeira Mendes, Maringá, Paraná. Acta Limnológica Brasiliensia, vol. 8, p. 207-220.

PINTO-COELHO, RM. 1998. Effects of eutrophication on seasonal patterns of mesozooplankton in a tropical reservoir: a 4-year study in Pampulha Lake, Brazil. Freshwater Biology, vol. 40, p. 159-173. http://dx.doi. org/10.1590/S1519-69842005000200017

REID, JW. 1985. Chave de identificação e lista de referências bibliográficas para as espécies continentais sul-americanas de vida livre da ordem Cyclopoida (Crustacea, Copepoda). Boletim de Zoologia, vol. 9, p. 17-143.

RIETZLER, AC., MATSUMURA-TUNDISI, T. and TUNDISI, JG. 2002. Life cycle, feeding and adaptive strategy implications on the co-occurrence of Argyrodiaptomus furcatus and Notodiaptomus iheringi in Lobo-Broa reservoir (SP, Brazil). Brazilian Journal of Biology, vol. 62, no. 1, p. 93-105. http://dx.doi. org/10.1590/S1519-69842002000100012

ROCHA, O. and MATSUMURA-TUNDISI, T. 1984. Biomass and production of Argyrodiaptomus furcatus, a tropical calanoid copepod in Broa Reservoir, southern Brazil. Hydrobiologia, vol. 113, p. 307-311.

ROCHA, O., SENDACZ, S. and MATSUMURATUNDISI, T. 1995. Composition, biomass and productivity of zooplankton in natural lakes and reservoir of Brasil. In TUNDISI, JG., BICUDO, CEM. and MATSUMURA-TUNDISI, T., org. Limnology in Brazil. Rio de Janeiro: ABC/SBL. 151 p.

SENDACZ, S. and KUBO, E. 1982. Copepoda (Calanoida e Cyclopoida) de reservatórios do Estado de São Paulo. Boletim do Instituto de Pesca, vol. 9, p. 51-89.

SENDACZ, S. 2001. Planktonic Copepoda of the Upper Paraná River Floodplain lakes (São Paulo and Mato Grosso do Sul, Brazil). Hydrobiologia, vol. 453-454, p. 367-374. http://dx.doi.org/10.1007/0-30647537-5_30

SILVA, ENS., ROBERTSON, BA., REID, JLW. and HARDY, ER. 1989. Atlas de copépodos planctônicos, Calanoida e Cyclopoida (Crustacea), da Amazônia Brasileira. I. Represa de Curuá-Una, Pará. Revista Brasileira de Zoologia, vol. 6, no. 4, p. 725-758. http:// dx.doi.org/10.1590/S0101-81751989000400019

SILVA, WM. 2008. Diversity and distribution of the free-living freshwater Cyclopoida (Copepoda: Crustacea) in the Neotropics. Brazilian Journal of Biology, vol. 68, no. 4, p. 1099-1106. http://dx.doi. org/10.1590/S1519-69842008000500016

SILVA, WM. and MATSUMURA-TUNDISI, T. 2005. Taxonomy, ecology and geographical distribution of the species of the genus Thermocyclops Kiefer, 1927 (Copepoda, Cyclopoida) in São Paulo State, Brazil, with description of a new species. Brazilian Journal of Biology, vol. 65, no. 3, p. 521-531. http://dx.doi. org/10.1590/S1519-69842005000300018

TER BRAAK, CJF. and SMILAUER, P. 2002. CANOCO Reference manual and CanoDraw for Windows user's guide: Software for Canonical Community Ordination (version 4.5). Ithaca: Microcomputer Power. 500 p.

TUNDISI, JG. and MATSUMURA-TUNDISI, T. 2003. Calanoida (Copepoda) species composition changes in the reservoirs of São Paulo State (Brazil) in the last twenty years. Hydrobiologia, vol. 504, p. 215-222. http://dx.doi.org/10.1023/ B:HYDR.0000008521.43711.35

WALSENG, B., HESSEN, DO., HALVORSEN, G. and SCHARTAU, AK. 2006. Major contribution from littoral crustaceans to zooplankton species richness in lakes. Limnology and Oceanography, vol. 51, no. 6, p. 2600-2606.

WETZEL, RG. 2001. Limnology Lake and River Ecosystems. 3rd ed. London: Elsevier Academic Press. 1006 p.

WILLIAMSON, CE. and REID, J. 2001. Copepoda. In JAMES, T. and COVICH, AP., org. Ecology and Classification of North American Freshwater Invertebrates. San Diego: Academic Press. 915 p. 